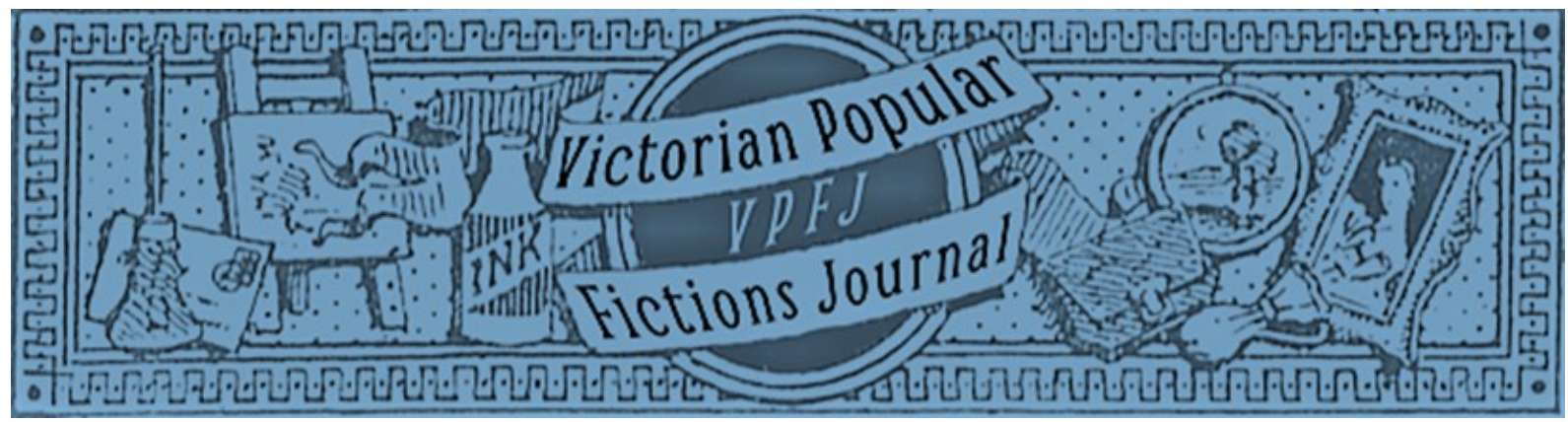

\title{
"Thief of the name of Kidd": Unscrupulous Opportunism and Cheap Print in Late Regency London
}

\author{
Brian Maidment
}

\begin{abstract}
William Kidd saw himself as a struggling small publisher of illustrated books operating during the 1830s in a marketplace that favoured large scale firms. His response to his perceived disadvantages was twofold. In seeking to reach a rapidly expanding cohort of leisure-based readers, Kidd deployed aggressive marketing policies that frequently sailed close to the law and generated considerable controversy. He was also less than honest about just who had written or illustrated his books. At the same time, he initiated new genres of relatively cheap illustrated publications based on the recreational interest and habits of an emerging lower middle class and artisan reading public. In particular, he took advantage of the wood engraving as a cheap reprographic medium, and employed highly capable draughtsmen such as Robert Cruikshank, Robert Seymour and George Bonner to illustrate his books and pamphlets. His pocket guides to British seaside resorts, his development of the illustrated reprints known as jeu d'esprit or Facetiae and his packaging up of sayings, mottos and nuggets of information into small format gatherings all show a lively minded and innovative response to the rapidly changing literary marketplace. Kidd's career suggests both the legally chaotic nature of the literary marketplace and the entrepreneurial opportunities offered to a shrewd if unscrupulous publisher in late Regency London.
\end{abstract}

\section{Keywords}

William Kidd; wood engraving; jeu d'esprit; Robert Seymour; Robert Cruikshank; comedy; caricature; piracy

Date of Acceptance: 8 December 2021

Date of Publication: 17 December 2021

Double Blind Peer Reviewed

\section{Recommended Citation}

Maidment, Brian. 2021. “'Thief of the name of Kidd:' Unscrupulous Opportunism and Cheap Print in Late Regency London." Victorian Popular Fictions, 3.2 (Autumn): 21-44. DOI: https://doi.org/10.46911/ TVBM5431

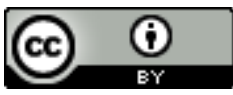

This work is licensed under a Creative Commons Attribution 4.0 International License. 


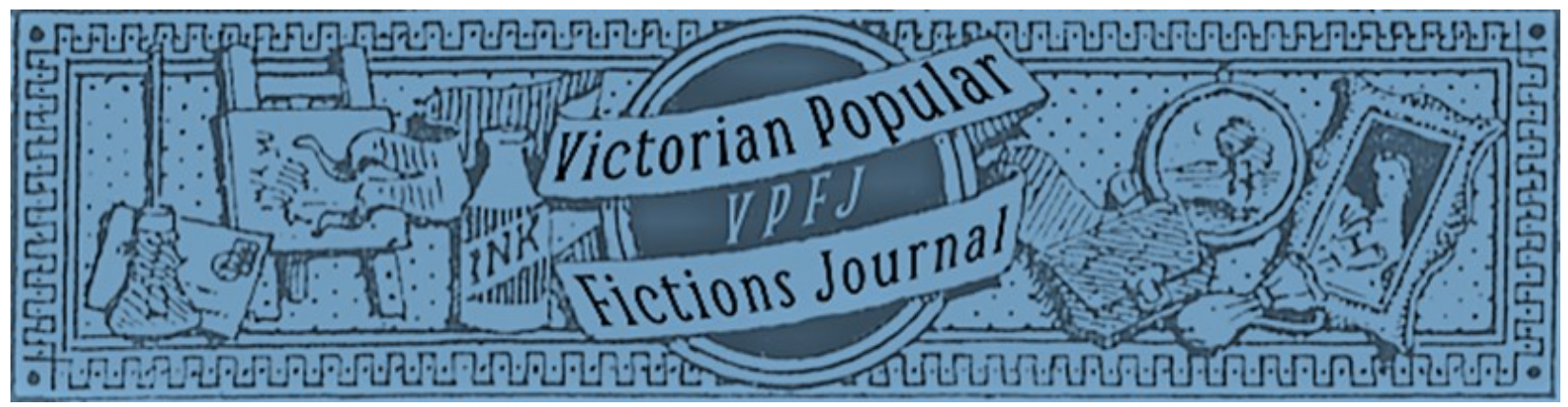

\title{
"Thief of the name of Kidd": Unscrupulous Opportunism and Cheap Print in Late Regency London
}

\author{
Brian Maidment
}

In the most detailed available study of William's Kidd's sharp practice as a small-scale publisher and bookseller operating in the 1830s, "The Two Versions of Sketches of Young Gentlemen," William F. Long notes that Kidd "operated on the fringe of the London bookselling community" and felt himself to be vulnerable to the machinations of more powerful and established rivals (Long 2020: 11). On however limited a scale, Kidd was, nevertheless, a significant publisher of cheap illustrated books in the $1830 \mathrm{~s}$, specialising in small-scale or pocket-sized books, many of them brief enough to be called pamphlets. He inaugurated an extensive series of popular guide books aimed at the supporting the leisure activities of newly mobile tourists, and was a major force in the publishing of jeux d'esprits - reprints of short humorous texts extensively illustrated by wood engravings. Robert Cruikshank was his most prized artist, but his lists drew on a range of significant illustrators including Robert Seymour and George Bonner. Kidd's publications thus made a significant contribution to the history of wood engraved illustration. He found new formal and generic shapes to circulate the diverting, the trivial and the informative as cheap literary commodities. Many of his publications were put together by gathering together miscellaneous sayings and pieces of information gleaned from already published sources. The innovative use of illustration and understanding of popular taste exhibited by Kidd's publications to some extent transcends the flimsiness of their content and gives him a minor but significant role in publishing history. This essay seeks to explore some of the tensions between entrepreneurial energy and business malpractice that characterise Kidd's career as a publisher. He was in many ways a characteristic figure of the restless inventiveness, innovative vision and economic uncertainty that characterised late Regency London print culture. 
Kidd was also a rogue who resorted to a number of sharp practices to sell his books. His advertisements falsely ascribed well known authors and illustrators to his publications. He continually exploited the Cruikshank name by implying the better-known George had contributed to books illustrated by the less distinguished Robert. He re-used images and texts shamelessly across his publications. His career as a publisher gives extensive evidence of the ruthlessness and lack of scruple that characterised the production of cheap mass circulation literature in the 1830s. Long's summary of Kidd's career acknowledges that "his practices sometimes crossed ethical and legal boundaries" (Long 2020: 9). This essay puts Long's conclusion - that Kidd deliberately "sought to mislead potential customers" about the authors and illustrators whose work he claimed to publish (Long 2020: 25) - more widely to the test. But it also seeks to understand how both innovation and unscrupulousness were important to Kidd's business and to consider the narrowness of the line between entrepreneurial initiative and foul play that are suggested by his activities in the literary market place of the 1830s.

The paper cover of one copy of the March 1834 monthly part issue of the Comic Magazine, published by the National Library Office, has been inscribed in ink with the mystifying accusation "Thief Kidd" (Comic Magazine series 4 March 1834). Turning a leaf, the title page carries a further vigorously scrawled indictment: "Published by thief of the name of Kidd - who pirated many of the works of George Cruikshank" - that concludes with the familiar flourish of the artist's signature. George Cruikshank's annotations here make it clear that at least some of Kidd's contemporaries considered him a bandit.
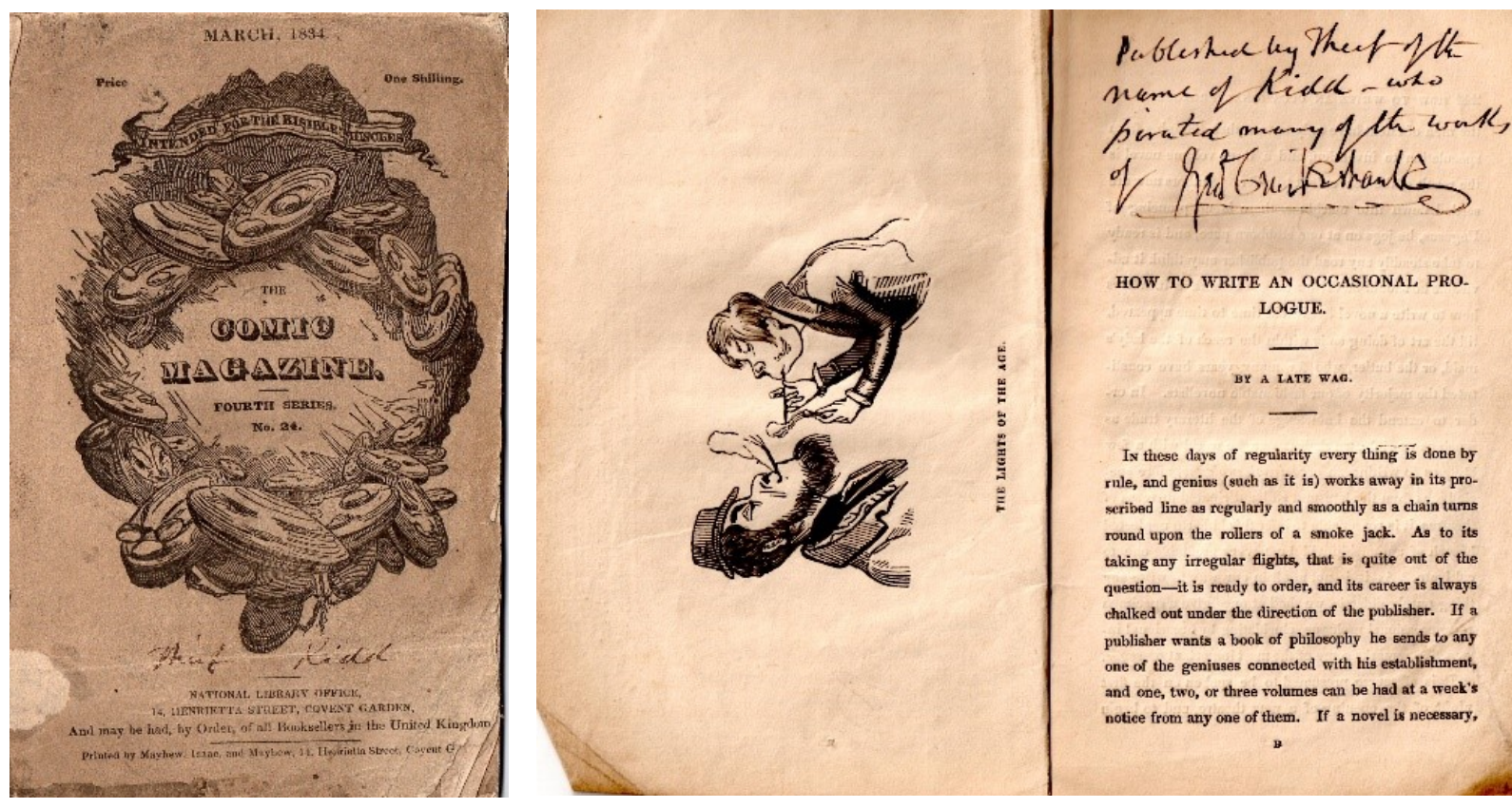

HOW TO WRITE AN OCCASIONAL PRO. LOGUE.

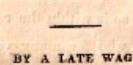

Is these days of reguiarity every thing is done by rule, and genius (such as it is) works away in its pro-

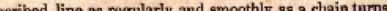
round upon the rollers of a smoke jack. As to its taking any irregular flights, that is quite ont of the question-it is ready to order, and its career is always chalked out under the direction of the publisher. If a publisher wants a book of pbilosophy he sends to any one of the geniuses connected with his establishment, and one, two, or three volumes can be had at a week's notice from any one of them. If a novel is necessary,

Figure 1. Monthly part of the Comic Magazine series 4, March 1834, inscribed by George Cruikshank.

What had Kidd done to provoke an outburst of such spleen that it was scrawled across a publication that carried no mention of his name? How could even the vestigial memory of Kidd rather than his continued presence continue to contribute to Cruikshank's sustained wrath? Kidd had been the first publisher of the Comic Magazine in March 1832, but the title had almost 
immediately been passed on to the Penny National Library, a raggedy and characteristically short-lived venture evolved by Gilbert Abbott à Beckett (the editor of the Comic Magazine) and Henry Mayhew (Anderson 2018: 30-35). Yet, even two years later, anything called the Comic Magazine brought Kidd back to Cruikshank in a wave of indignation.

Kidd's protracted disagreement with George Cruikshank is well documented not just in the written record but also in Cruikshank's own work. One plate in My Sketch Book (1834), "A Chapter of Noses," shows a lofty Cruikshank holding Kidd off the ground by means of a pair of tongs clamped on his snub nose:



Figure 2.

George Cruikshank Image from My Sketch Book (1834) showing Cruikshank holding up William Kidd by the nose.

This image, described at length by Patten in his wonderful biography of Cruikshank, (Patten 1992: 360-368), was a final expression of frustration on Cruikshank's part over Kidd's long-standing refusal in publicising his many illustrated books to name exactly which Cruikshank had drawn for them. Patten suggests the ways in which the row between George Cruikshank and Kidd was sustained through letters to the press, but which was enacted more thoroughly in the graphic allusiveness of "A Chapter of Noses." 




Figure 3. George Cruikshank ‘A Chapter of Noses’ from My Sketch Book (1834).

As Cruikshank's plate makes clear, George Cruikshank had in fact only been commissioned to draw for one of Kidd's publications (Dalton's Gentleman in Black from 1831) but anyone reading Kidd's lists would have imagined that the constant references to "illustrations by Cruikshank" could only have referred to George rather than his less well known and less highly rated brother Robert. Attempts by both brothers to put the record straight in 1834 through letters to the press and the threat of legal action failed, and George exacted the only possible remaining revenge through publishing his image of Kidd wriggling feebly as a result of the "most approved method of pulling a fellow's nose." Patten concludes that "neither brother could stop Kidd's misleading puffery" (Patten 1992: 369).

Many of Kidd's advertisements were extremely and disingenuously misleading. His Book of Books, for example, claimed on the title page to be illustrated by "G. and R. Cruikshank, Seymour and Bonner," but only Bonner and Seymour appear as signatories, with Seymour contributing very few and insignificant images. Kidd never quite had the gall to claim outright that George Cruikshank drew for the Comic Magazine, perhaps persuaded that Seymour was by this date sufficiently distinguished to stand on his own. But it seems likely that Kidd had nonetheless managed to insinuate the idea that Cruikshank had drawn for his magazines and publications into public consciousness. Even the volumes of gathered brief publications that characterised his output in the mid-1830s sought to take advantage of George Cruikshank's fame without offering any of his work. The undated Cruikshank's Comic Album, for instance, brought together a wide choice of pamphlets illustrated by Robert Cruikshank but contained nothing by his brother. And the opening publication in the 
collection, Valpurgis, was not illustrated by either Cruikshank but was rather the unacknowledged work of Robert Seymour. At best the title of the compilation was disingenuous, at worst deliberately misleading.

Details about Kidd's life beyond the brief Dictionary of National Biography entry by Watkins and Matthews and a slightly longer account in the Dictionary of Literary Biography by Browning are few and far between. A Londoner born in 1803, he worked initially for the publishers, distributors and booksellers Baldwin, Cradock and Joy. His connection with Baldwin, Cradock and Joy introduced him to a sophisticated publisher with wide interests in books, periodicals and prints, especially those containing high quality illustrations, at a moment in the 1820s when the firm was producing expensive and highly prestigious books. Their list featured large editions of Maria Edgeworth's books alongside important publications by John Dalton and James Mill, several major botanical books with coloured plates, the significant 1822 Nicholls edition of Hogarth's work, atlases and maps, many produced for the Society for Diffusion of Useful Knowledge, the yearly Annual Register, and a number of well-known magazines including the New Sporting Magazine (1831-1840), the Westminster Review (1824-1914) and the Retrospective Review (1820-1828). But there were also publications, such as the multi-volumed Useful Knowledge series, aimed at the emerging market for cheap self-educational guides. Setting out on his own in the late 1820 s as a bookseller, Kidd began to publish his own works, one, the weekly London Journal (1852-54), bringing together his publishing business with his interests in natural history, especially ornithology. He was at his most active as a publisher in the early 1830 s, eventually selling out his business to concentrate on his interests in natural history, which included numerous publications and lectures mainly published in the twenty years before his death in 1867. As Matthews and Watkin tactfully describe him in the ODNB, he was an "independent and eccentric thinker and talker on religious and social subjects" who issued "a long series of tracts and essays," which "are either weakly imitative of Leigh Hunt, or characterized only by ignorance and superficiality." A brief glance at some of these ephemeral outpourings suggests that Kidd in later life became something of an advocate for the kinds of clichés, apothegms and facile quotations with which he cobbled together the most trivial of his publications in the early 1830 s. Today, no doubt, he would have become an internet wellness guru or motivational speaker. He is, nonetheless, a much more interesting publisher than this biographical summary might suggest and certainly something more than a charlatan.

Kidd's publishing activities do not form an easy subject for scholarly commentary. Many of his publications were ephemeral and are, despite his aim to reach out to a mass reading public, now confined to the rare book rooms of research libraries. Fortunately, his interest in illustration and his widespread use of wood engravings by named artists have rendered his publications of interest to collectors and bibliophiles, which, along with his practice of binding up and reprinting separate publications in volume form, has led to the preservation of many flimsy texts. Nonetheless, survival is patchy. Most of his publications were published anonymously, and, when not stitched together from pirated texts, presumably authored by hired literary hacks. Few of his publications are dated, so establishing a chronological sequence of his output is extremely difficult. Re-issues, which were frequent, seldom gave details of previous editions. Kidd often used different titles for re-issues of a work in the hope of inveigling customers into believing that they were buying something new, which is confusing. His lists, which were peppered with exaggerated claims, were often misleading and unhelpful. 
In pursuing the dialogue between innovation and roguery that characterised Kidd's career, it may be easiest to begin with his use of a range of sharp practices, already glimpsed in his dealings with George Cruikshank over the false claims over the contributors to the Comic Magazine. Browning in the Dictionary of Literary Biography points to further examples of Kidd's willingness to invent or foster controversy as a way of publicising his texts. He issued advertisements, for example, spuriously claiming that plagiarized copies of his 1832 illustrated edition of Pilgrim's Progress were in active circulation, and warning that purchasers should ensure that they bought Kidd and Gilbert's de-luxe edition and not the inferior copy. In a similar capitalization of controversy, he issued advertisements that emphasised the scandalous content of the 1832 anthology of Living Poets and Poetesses (Dictionary 162). More substantially, Kidd's aggressive approach to marketing the Comic Magazine led him into arguments, not just with artists but also with writers, arguments that were carried out, I suspect gleefully on Kidd's part, in the extremely public pages of major journals. Kidd advertised the fourth issue of the Comic Magazine in the Athenaeum with characteristic bravado: "Literary Phenomenon! Several Comic Articles! Nineteen Humorous Engravings! Price Only One Shilling!!!" the headline bellowed, followed by a spirited announcement of "the most racy and burlesque humour" shown by Seymour's illustrations. Then comes a list of "authors already retained" as contributors, and of others for whom the proprietors held "hopes of obtaining... [their] zealous co-operation." These lists were, of course, spurious, and had already been challenged by one of the named potential contributors, Thomas Hood. The Athenaeum, while retaining a semblance of decorum and impartiality, was nonetheless happy to publish an exchange of letters (Correspondence, Athenaeum No. 245 July 7 1832, 461) between the Comic Magazine's editor Gilbert à Beckett and some of the writers "already retained" and held "in hope of retaining." First came a letter from Thomas Hood complaining of "double dealing" by the Comic Magazine. Hood's letter provoked a disingenuous response from à Beckett dated 9 July 1832 in which he claimed not to understand Hood's accusations. À Beckett followed up these comments with another mischievously provocative letter, saying that he had written to Hood but not been given a reply, thus remaining hopeful of Hood's participation, and that he was puzzled by Hood's complaints. Letters from two other potential contributors, Poole and Colman follow, both emphatically rejecting all possibility of their contributing to the Comic Magazine. Poole's letter ends with a scathing postscript:

Would the gentlemen of the 'Comic Magazine' take it as too serious a joke if you were to ask them, how many of the names which they have dragged into their advertisements they have the slightest possible authority for promising to or good-natured and unsuspecting friend PUBLIC, as contributors to their work?

Athenaeum No. 246 (July 14 1832) 461.

Nothing I have read about Kidd or à Beckett suggests that Poole's disdain was anything other than justified.

A not dissimilar dispute occurred in 1834, again acted out in public. It concerned Kidd's advertisements for the three volume Cruikshank at Home. In this instance, Robert was the complainant, arguing that, in not ascribing his work specifically to him, Kidd had made it seem that he, as the less well-known Cruikshank, was trying to trade off his brother's celebrity. Kidd's response was to publish the correspondence with Robert Cruikshank together with new advertisements for Cruikshank at Home which appeared in the Spectator on 19th and $21^{\text {st }}$ April 1834. The advertisements remained defiantly unclear about exactly which Cruikshank was 
responsible for the illustrations in the three volumes, and, in Patten's account of the row, resulted in Kidd "immediately capitalizing on the publicity" (Patten 1992: 16). Patten further notes that George Cruikshank "was not amused by any incident that might confuse or obscure his singular identity as an artist. He depended on a brand-name identification for his livelihood" (Patten 1992: 18).

Kidd's disingenuous casualness over naming potential authors who had no intention of contributing to his publications is more obviously dishonest than his tendency to re-publish illustrations across several publications without any notice of their previous appearance elsewhere. It is possible, of course, to describe the unacknowledged re-use of wood engraved blocks in several different contexts as good business sense rather than sharp practice, especially at a time when illustrations submitted to a publisher legally belonged to the firm. Kidd was understandably keen to get the maximum use from the blocks he commissioned for his publications, presumably without asking for permission for their re-use. The result was that illustrations turned up in a variety of publications without any close relevance to the accompanying text. The illustrations Kidd had presumably commissioned from Robert Cruikshank and Seymour were particularly prone to appearing elsewhere. Seymour's illustration to "Neck or Nothing" from The Odd Volume, for example, originally the source for a prolonged meditation on "The Art of Tying the Cravat" (The Odd Volume 280) turned up as the frontispiece to Sayings Worth Hearing where it was tenuously linked to a few lines on "Tying the Cravat," optimistically billed as a "Secret Worth Knowing" by the caption to the frontispiece (Sayings Worth Hearing (32).

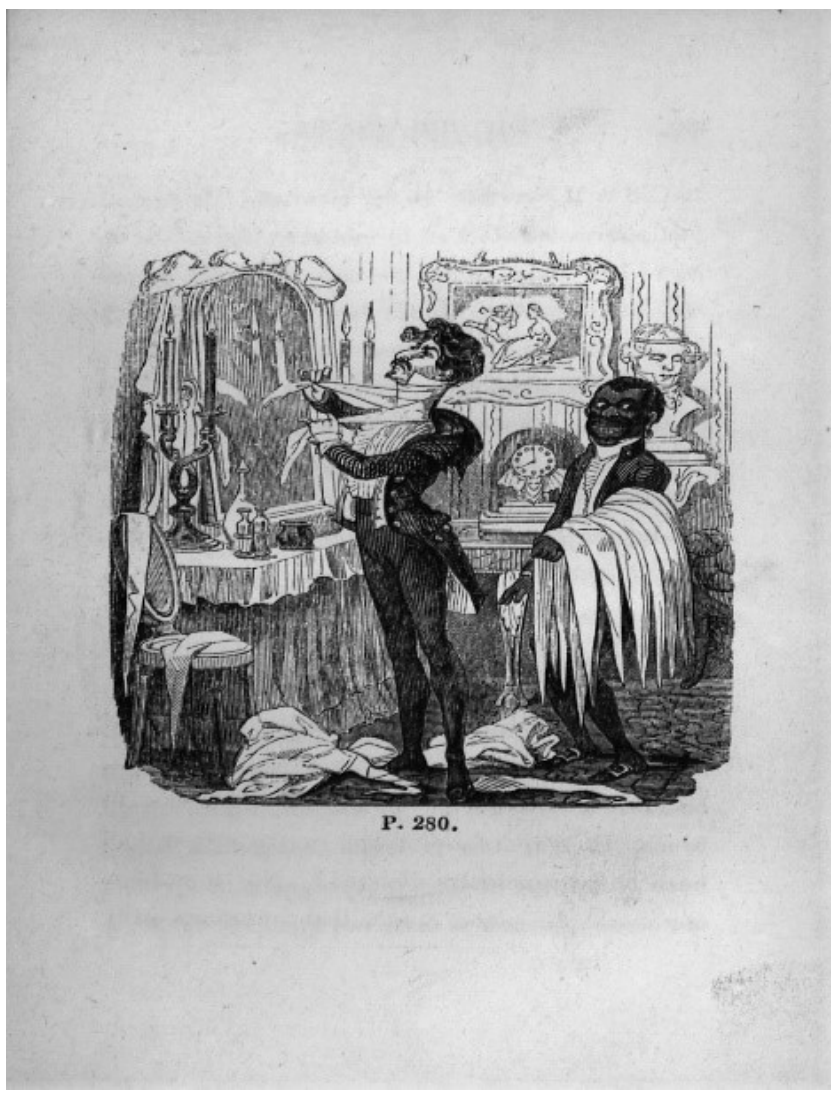

Figure 4.

"Neck or Nothing," a drawing by Robert Seymour for a wood engraving published in three of Kidd's publications: The Odd Volume, Sayings Worth Hearing and Characteristic Sketches of Young Gentlemen. 
The image shows a black servant holding out an armful of unfolded cravats to a moustachioed and dandified figure who is attempting to complete his toilette in front of a mirror. Failed and creased cravats are strewn on the floor, a clock in the background registers eight o'clock suggesting the pressing need to get the business done, while an elaborately framed picture of cupid shooting an arrow at a scantily dressed young woman underlines the purpose of all the fuss. The image also appeared as the frontispiece to Quiz Junior's Characteristic Sketches of Young Gentlemen above the title of "The Dandified Young Gentleman, a Wrinkle," a satirical work that mocked the vanity and social pretentions of fashionable young men. ${ }^{1}$ Despite the engaging pun on wrinkle (simultaneously a damaging crease in the cravat and a piece of useful advice), the text actually denies the presence of an elaborated folded cravat: "but, tell me, where is the collar? There is no collar. Scarcely is there room for the embroidered satin stock, inserted behind the crow's nest, which well nigh hides it; much less is there room for a collar" (Characteristic Sketches 41). Because there cannot be a cravat if there is no collar, Kidd's reuse of Seymour's image of cravat-tying calls attention to 1830s trade practices of publishing images with only an attenuated relationship, if any, to the adjacent text. In the context of Kidd's restless economising ambitions, the practice seems to derive from the wish to reuse images without paying for additional ones, either capitalizing on consumers willing to enjoy an image on its own or training consumers to do so.

If there is some semblance of relevance in the re-use of these images, other re-publications were less obviously tied to their context. An illustration, probably by Robert Cruikshank, used in the first series of Cruikshank at Home (Cruikshank At Home First Series 65) to illustrate the "whisker fiend" for a piece on the absurdities of contemporary moustaches and the "smoking mania" re-appears, for no obvious reason, as the frontispiece for Streams of Knowledge, from the Fountains of Wisdom. This facile collection of "choice extracts culled from the works of the immortal Shakespeare and the wisest men who have flourished since the days of King Solomon" offers the image under the tag drawn from Shakespeare, "All the world's a stage, - and all the men and women merely players," thus ignoring the specific details of the illustration in favour of it offering a general commentary on the theatre of street life.

To take another example, London and all its Miseries features two wood-engraved embellishments, known as vignettes, by Robert Seymour. The title page includes a small image (Figure 5), signed "RS," of a gentleman in buckskin trousers being soiled by soot emanating from the bag of a passing sweep's boy. The incident is watched by an interested passer-by in tattered clothing, and forms a classic graphic exposition of the "miseries of London" tradition in which minor discomforts are mock heroically depicted as misadventures so serious that they are barely to be endured (Maidment 2013: 50-7).

${ }^{1}$ This publication should not be confused with Dickens's Sketches of Young Gentlemen (1837) nor with Edward Caswall's (Quiz, Junior) Sketches of Young Ladies. For more discussion of these publications see Schlicke 2012: 7-28. Long's detailed discussion of the publishing history of these texts concludes "Nor can it be denied that William Kidd, by advertising his product as illustrated 'by Cruikshank.' by declaring it to be a companion volume to Chapman and Hall's Sketches of Young Ladies, and by choosing for its author a cognomen which further linked it to that previous publication, sought to mislead potential customers" (Long 2020: 25). 


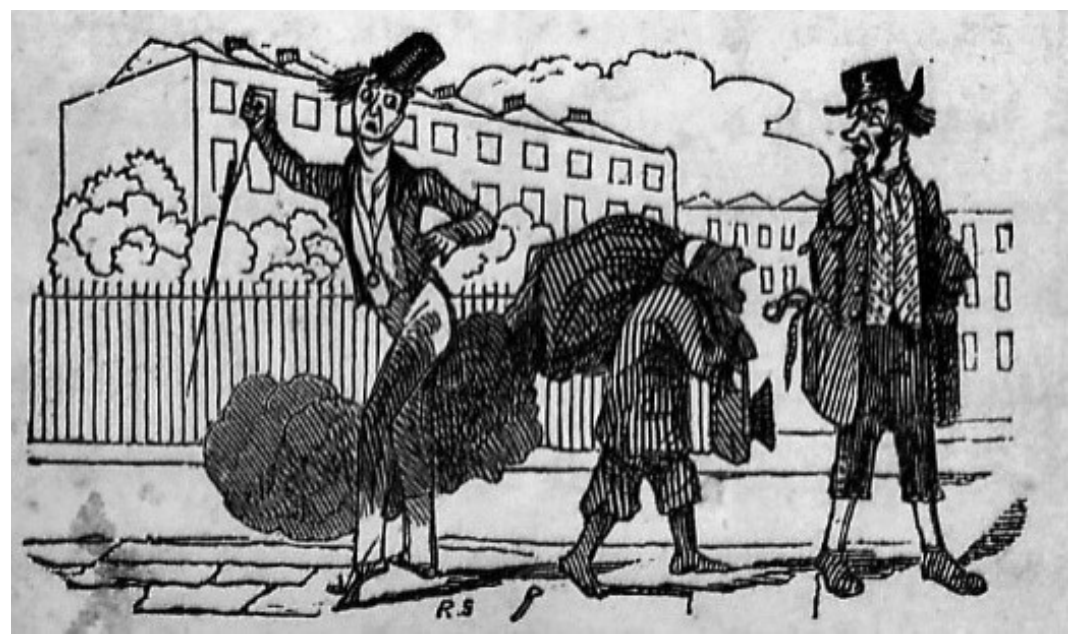

Figure 5.

Robert Seymour title page vignette for London and All Its Miseries.

This image by Seymour had already been used in The Comic Offering and points to Kidd's unacknowledged re-use of an image already published in The Odd Volume (Odd Volume 242), thus suggesting Kidd's willingness to re-use illustrations images from previous publications. The final illustration in London and All Its Miseries (Figure 6), showing a crowd pushing its way into the pit of a theatre, can also be found in Seymour's Comic Album for 1832 (Seymour's Comic Album 140), again suggesting that Kidd made widespread use of available blocks regardless of their content.

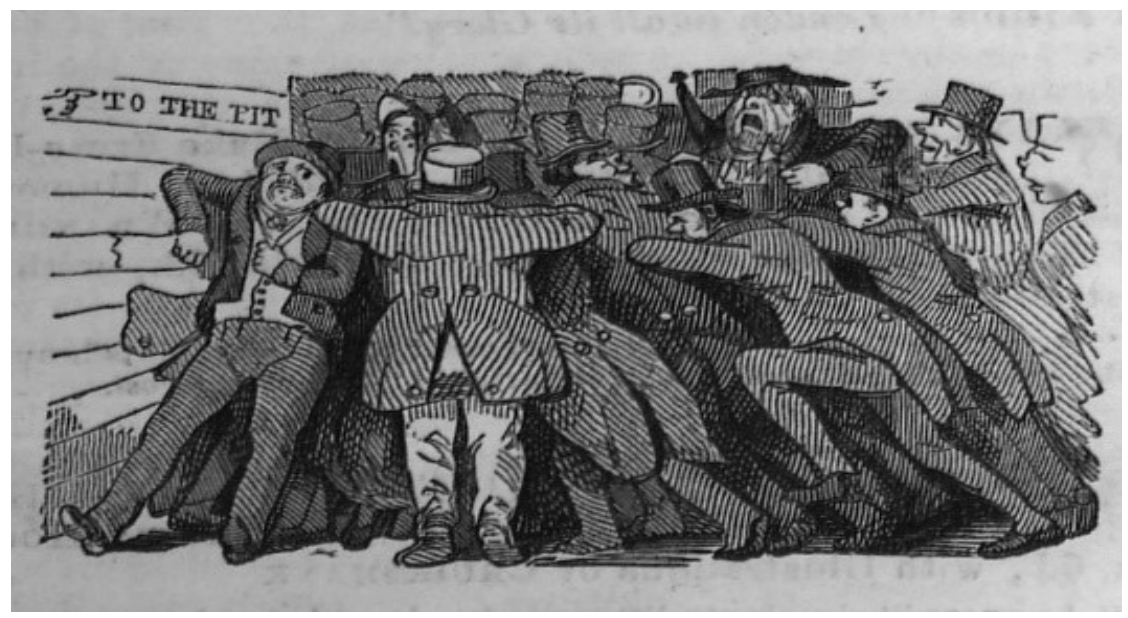

Figure 6.

Drawing by Robert Seymour for a wood engraved vignette published in both London and All Its Miseries and Seymour's Comic Album for 1832.

While there is obvious economic sense in re-deploying illustrations in this way, it is worth considering the point at which Kidd's readers would have become irritated by being offered the same images again and again. It is also very unlikely that Kidd's artists ever saw any further payment for their re-published work, or had any say over its use as was common practice before 
the passage of the Fine Arts Copyright Act in 1862. The re-publication of images in differing formats regardless of the changed context is an interesting aspect of the work of jobbing draughtsmen in the $1830 \mathrm{~s}$, and relevant to a consideration of the nature of the visual pleasures offered by small-scale comic wood engravings. Whatever the ethics of reusing works commissioned for prior publications, the circulation of these small-scale wood engravings gave pleasure to many and helped establish consistent work opportunities for draughtsmen and engravers.

A more abstract accusation that might be made about Kidd's publishing career is his glorification, codification and commodification of triviality. The cheap weekly magazines of the 1820 s and early 1830 s, led by the example of The Mirror of Literature (1822-1841), depended on miscellaneous content drawn from other sources in the form of extracts, snippets, translated stories and reviews that reproduced large chunks of the text that was supposedly being reviewed. Compilation and accumulation of this kind ran from legitimate re-use through accepted codes of re-appropriation to blatant theft. It is no surprise to learn that a magazine launched in the early 1830s was actually called The Thief. Edited by Gilbert à Beckett and Henry Mayhew, The Thief was perhaps the most mendacious magazine from the generally uninhibited world of 1830s journalism. In an interesting essay that addresses many issues to do with literacy piracy in the 1830s, Catherine Feely notes that "The Thief was framed from the outset as a response to the 'larceny' of others ... the editors argued, if perhaps with tongue in cheek, that their 'thievery' was at least honest, perhaps even moral" (Feely 2014: 499). The magazine's opening editorial claimed it "to be edited by the light-fingered gentry, and will consequently contain no heavy articles - the magazines, the various periodicals will be our plunder; they will be, as it were, the shell and the husk, we the kernel of literature; they are the fatness, but we are the marrow of fatness" (Feely 2014: 499). For Jon Klancher, such a relentless pursuit of the previously published and trivialising snippet in the miscellanies of the 1820s and 1830s "displaces all discourses of political argument, philosophical speculation and cultural discrimination....Excluded from the dialogues of cultural power, the mass reader discovers an allegorical world overcrowded with signs" (Klancher 1987: 81). To the extent that Klancher has a point, trade practices as they were evolving in the 1820 s and 30 s at the low end in miscellaneous anthologized trivia excluded the mass reader from the nation's political and cultural concerns.

Beginning in the 1820 s, Kidd's publications certainly condescended to the average reader. Firstly, they seemed to underestimate the attention span of the target audience. As if to complement and exploit the abbreviated items that formed the main content of the weekly miscellanies, many of Kidd's publications were extremely small in size and, often, in content as well. Much of what he published first appeared in pamphlet form, as if testing popular approval before being translated into accumulated volumes with more substantial bindings. But even these volumes were unusually small in size as if to suggest that anything larger would just take too long to read. Such smallness frequently stepped beyond a reduction in scale to "pocket sized" and veered towards the miniature. Encased within publishers' limp cloth or embossed cloth boards and embellished with attendant if sometimes sparsely scattered small-scale wood engravings, Kidd's publications revelled in the aesthetics of smallness. The modest claims of the publication's content and illustrations asked only for an equally modest amount of the owner's space, 
asking for a large pocket or substantial reticule let alone a bookshelf. As the address "To The Reader" that introduced Sayings Worth Hearing and Secrets Worth Knowing put it, "so extensive a collection of varied matter, and so piquant a quality as the present, has never yet appeared in so small a space." Such an aesthetic of smallness assumes a small attention span whatever its other virtues.

It would seem that Kidd similarly assumed that the reader of small attention span would also not notice, or not mind, the varieties of repackaging so much content was subjected to. In one volume, the thirty four pages of Sayings Worth Hearing were combined with two further pamphlets: Golden Records; A Miniature World of Wisdom, which laid out enough wise sayings in alphabetical order of topic to fill up another thirty two pages, and a further thirty two comprising Streams of Knowledge from the Fountains of Wisdom, to build (if that's the right word) into Kidd's Golden Key to the Treasures of Knowledge. This cornucopia of wisdom - "a rare collection of gaieties and gravities" according to the title page - was announced as being "illustrated by G. and R. Cruikshank, Seymour and Bonner." Here, too, cutting and pasting is evident, for in practice the illustrations were limited to a full-page frontispiece (brought in, as already noted, from another earlier publication), a tiny title page vignette that might have come from any printer's stock, and an opening illustrative capital letter (again a stock element) in each pamphlet, with an additional tail piece to the third that showed a wrecked rowing boat with "Finis" engraved into its timbers. One great advantage of these pamphlets in similar format was the ability to build up volumes from different combinations. Kidd's Silver Mine, for example, combines the two Streams of Knowledge (both present in this instance) with the two parts of Golden Records; A Miniature World of Wisdom. Despite being two parts golden, Kidd's Silver Mine was presumably so confusingly titled in order to differentiate it from Kidd's Golden Key, something of a deception given that the two publications shared fifty percent of their content. There is a certain amount of playfulness in the grandiloquence of the marketing copy and in the immediately evident discrepancies between the publications' various claims to wisdom and knowledge and their appearance as rather insignificant and slapdash objects. Even so, as the physical embodiment of a "Miniature World of Wisdom," these little pamphlets fall rather short of the sublime.

If Kidd catered to an emerging low-end market with small portions and reheated fare, he also included dishes designed for those hungry for social instruction, several of his publications thus offering advice on what would now be called "relationships." ${ }^{2}$ Again published in a small format with wood engraved illustrations, such publications exploited the strand of "serio-quizzical...refinement" advertised in the subtitle of The Modern Brummell and written by "one of the cognoscenti." "Serio-quizzical" is a useful term for describing Kidd's publications on etiquette. It suggests the ways in which the flood of serious advice was frequently undercut by a sardonic undertow, thus allowing the reader to mock the pretensions of prescribed social behaviour while simultaneously absorbing the rules necessary for entry into polite society. If men were tasked with acquiring Regency refinement, women were directed towards Teasing Made Easy - showing How to Excel in that most fashionable of all Modern Accomplishments by a "Popular Female Practitioner." Kidd clearly took the task of defining refined good taste for socially ambitious readers seriously, stepping beyond manuals on

\footnotetext{
${ }^{2}$ The titles described in this paragraph are taken from the lists of Kidd's publications bound to volumes that he published. I can't pretend to have seen copies of all of them, and of course publisher's lists need to be treated with considerable caution, but even allowing for high levels of puffery, the nature of Kidd's appeal to emerging lower middle class social and cultural aspirations is clearly visible.
} 
"courtship - matrimony -house-keeping" to instructional volumes on "fashionable cookery," "book-keeping" and "early education." Chesterfield Modernised provided "A Mirror of Etiquette, Gentility and Politeness" and formed one of many publications addressed towards the anxieties of readers aspiring to the manners and habits of mind appropriate to urban gentility. Perhaps publications of this kind, with their insistence on punctiliousness and good breeding, invited the reader to mockery as much as emulation, but Kidd's lists, however optimistically, ascribe multiple editions of such titles.

It is difficult to say how far the differing print genres at the centre of Kidd's list - travel guides, jeux d'esprits, and self-help instructional literature - were aimed at constructing a single entity identified by the publisher as his niche market. All three literary kinds were dependent on a book-buying public with increasing time for leisure reading and newly anxious about how to manage their public and domestic lives. Publications of this kind also aimed to offset their instructional or literary ambitions with carefully calibrated pleasurable elements, most obviously extensive illustration but also a smallness of scale and ambition unlikely to put off potential customers with little experience of leisure reading. They were both useful and, within the constraints of their cheapness, attractive. Kidd's books of all kinds did not require a sustained attention. They were to be dipped into: they offered quick small-scale satisfactions, appropriate to the tastes, needs and habits both of a lower-middling class of readers seeking access to leisure reading and of more established readers seeking relatively undemanding amusement and information. Whether for travellers seeking practical information about their destinations, for anxious lower-middle-class urbanites transfixed by social anxiety or for leisured readers seeking amusement, Kidd's publications addressed the interests of a wide swath of people with enough wealth, leisure and education to want to buy books but wanting their reading to be either useful or relatively undemanding as well as aesthetically pleasing.

In any case, Kidd's list evolved in the mid-1830s to centre on two more ambitious and, indeed, substantial publishing projects, although both, like the Streams of Knowledge, remained dependent on a proliferation of relatively modest units. The remainder of this essay provides a summary of what seems to me Kidd's substantial achievement as a lively presence and as an innovator in the development of mass market illustrated literature in the 1830s. It builds on the accounts of Kidd by Browning (1991), Long (2020) and Maidment (2021), but concentrates attention on two print forms widely visible in his lists of publications from the $1830 \mathrm{~s}$, the pocketsized travel guides and the illustrated jeux d'esprit. Kidd's small-scale illustrated publications suggest an astute analysis of the market opportunities offered by readers seeking amusement or information but unwilling to engage with the more didactic mass of illustrated "useful knowledge" publications aimed specifically at artisan readers. A recognition of the value of the wood engraving as both a descriptive and expressive medium for illustrating texts was central to his assessment of the market potential for these kinds of publications. In addressing such a closely defined segment of the market and remembering Long's comment that Kidd, as a small-scale publisher, "operated on the fringe of the London bookselling community" (2020: 11), his willingness to challenge the protocols and practices of contemporary publishing even to the point of illegality is perhaps unsurprising.

Kidd's most extensively developed project was the series of "Picturesque PocketCompanions to most of the places of fashionable resort in Great Britain." Despite their small-scale format, the Companions were marketed to a readership with the necessary resources to undertake leisure visits and thus a set of classes that enjoyed various amounts of disposable 
income. Perhaps as a consequence, the volumes were extremely varied in price. As well as regular editions costing between two and seven shillings, many volumes were also produced in India paper editions, making them even more easy to slip into a pocket or reticule. Costing between 3s. 6d. and 14 shillings, the India paper editions were expensive. All the Companions explicitly named their illustrator, G.W. Bonner, one of Kidd's staple artists and already a well-known and respected engraver. Both Bonner's name and the very large number of illustrations in each volume formed a considerable element in Kidd's catalogues, along with claims about the quality of book production in the series. Engen notes that at least some of the Companions and Kidd's New Guide to the "Lions" of London (1832) were printed by the prestigious Whittingham Press. (Engen Dictionary 27) Charles Whittingham had founded the Chsiwick Press in 1811, and it had steadily built a reputation for both fine printing, especially illustartions, and for cheap editins of classic literary texts, often using 'India paper' editions. This is further evidence of Kidd's interest in attracting a relatively affluent clientele to his books, however utilitarian their content.

While again stressing handiness and portability, Kidd makes interesting use of the term "picturesque" in describing his Companions. Alluding most obviously to the coastal scenery and the pleasurable attractions of the seaside described in the guides, "picturesque" also suggests the possibility of being pictured, a potentiality vigorously followed up by the Guides. The fashionable resorts can be pictured here because they are amenable to the newly recognised ability of the wood engraving to offer cheap visual accompaniment to a text in however compact a form. Like type itself, wood engravings were relief work that could be stereotyped at the same time as the text, thus allowing images and words to appear together on a single page. Wood engravings of topographical subjects had become a staple element in in the weekly periodicals and miscellanies of the 1820s and 1830s (Maidment 2010: 376-7). While such images had familiarised a wide readership with the physical appearance of British resorts, the expanded opportunities to visit such locales opened up by the railways gave a new energy and significance to the graphic representation of place. Despite a modesty about the scale of aesthetic ambition provided by these texts, nonetheless they gave the reader, often at a low price, a semblance of the visual pleasures traditionally reserved for metal engraving and etching. They also served as both an inducement to travellers to take sightseeing trips and, potentially, as a visual record of places seen and enjoyed. Kidd's advertising copy made clear the scale of investment required to produce such a series by noting that "The Production ... has cost the Proprietor $£ 7,000 . "$ With each volume containing up to 140 illustrations, such a substantial sum, even allowing for Kidd's usual puffery, I s unsurprising, especially if the day-to-day costs of on-site visits for author and artist are included.

Published between 1831 and 1835 and frequently reprinted in undated form, the Picturesque Pocket Companions, along with another series called Steam Boat Companions, were aimed at those travellers venturing out of London into popular resorts like Margate or Ramsgate, or to the Hampshire coast. ${ }^{3}$ Kidd's series was undoubtedly heavily indebted to publications like the Leigh's New Picture of London (1830), a small format but wide-ranging compendium of information for the metropolitan visitor, as well as to the continuing flow of topographical articles in magazines like The Mirror of Literature (1822-49), The Portfolio

\footnotetext{
${ }^{3}$ The geographical reach ran from Thanet to the Isle of Wight and took in Brighton, Hastings, St. Leonard's Margate, Herne Bay, and Southampton.
} 
(1823-25) or Arliss's Pocket Magazine (1818-33). While the Picturesque Pocket Companions were generally informative and factual in tone, Kidd was also publishing in the 1830s guidebooks in the "serio-quizzical" mode that seemed to form a default position for the widespread deployment of the comic wood engravings by Robert Cruikshank, Bonner and Seymour. The originality of the guides and companions was largely comprised by their convenience, cheapness and willingness to abandon elaborate engraved picturesque illustration for linear naturalistic wood engravings that could be dropped at will into the pocket-friendly pages. London was overwhelmingly Kidd's favoured topic for guidebooks, combining an appeal to out-of-town visitors with helpful information for Londoners keen to explore their increasingly vast city.

One of his most inventive works, The Book of Books, or, London as It Is and as It Ought To Be, ingeniously adapted the four-pamphlet-as-a-book format that Kidd engineered for Kidd's Silver Mine to the needs of a visitor to London.

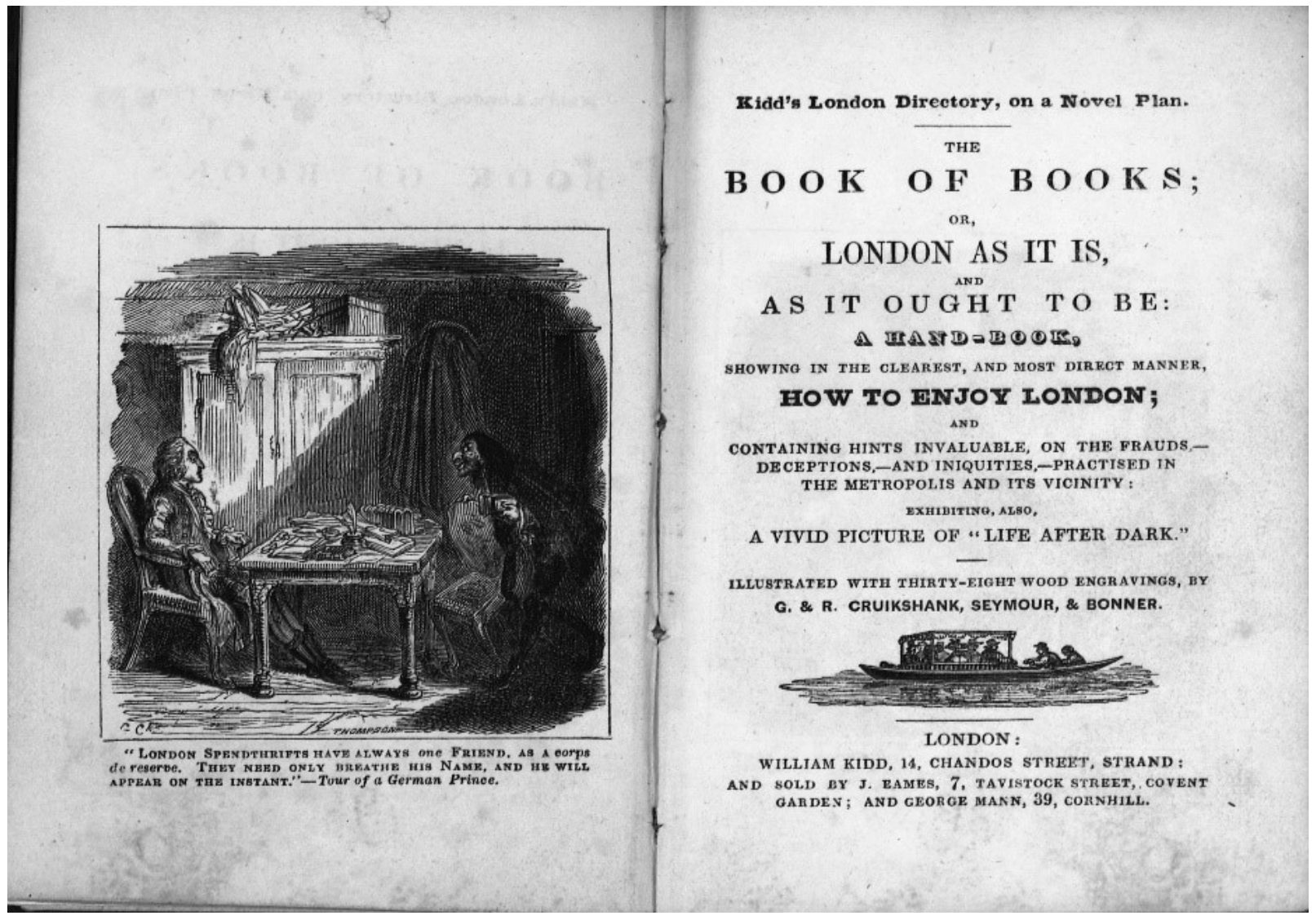

Figure 7.

Frontispiece and title page of The Book of Books.

The Book of Books divided itself in halves, with two elements (London In All Its Glory and The London Ambulator) offering straightforward tourist information accompanied by a good number of vignette illustrations showing places of interest, while two more (London And All its Dangers and London And All Its Miseries) pruriently elaborated the trials, tribulations and pitfalls that 
awaited the unwary visitor. As well as a tonal difference between these elements, with the latter two adopting something of the knowing and "serio-quizzical" tone that appeared in so many of Kidd's Travel companions and instruction manuals the illustrations were similarly in opposing modes, with the documentary picturesque images in the first two pamphlets replaced by comic frontispieces and vignettes that owed their manner to the kinds of humorous and tumultuous images of urban scenes that George Cruikshank had been producing in the late 1820s to illustrate metropolitan street life in such works as Mornings at Bow Street. Despite the pretence of social concern ("as it is and as it ought to be" - see Figure 7), The Book of Books suggests something of a metropolitan disdain for the naivety and credulity of provincial visitors to London.



Figure 8

Frontispiece and title page from London and All Its Miseries.

The second major element in Kidd's list in the 1830s was a sub-genre dubbed as either "facetiae" or "jeux d'esprits," a kind of publication, short displays of wit, that enjoyed a brief flare of popularity in the early years of the 1830s. The thirty or so facetiae or jeux d'esprits that Kidd and other publishers brought out between 1829 and 1831 perfectly embodied what one contemporary reviewer, cited anonymously in the "List of New and Popular Works" published by Kidd and bound into copies of Cruikshank's Comic Album, described as a "splendid production for a small bagatelle." As well as Kidd, Alfred Miller (later Marsh and Miller), Effingham Wilson, 
Thomas Griffiths and Lupton Relfe issued works in this genre, but Kidd seems to have garnered in all these publications and reprinted them as both individual publications and as gathered volumes. ${ }^{4}$ Texts for the facetiae were largely drawn from the minor works of well-known authors (including Mary Wollstonecraft, Coleridge, Southey and Thomas Hood) or from custom-written, extended and perhaps dashed off comic poems by prolifically versatile writers like Thomas Dibdin and W.T. Moncrieff. These pamphlets recalled in their form, if not their content, the more outspoken responses produced by William Hone and George Cruikshank to the political controversies generated by the scandalous behaviour of the Prince Regent and his wife Caroline in 1819-1820. While a response to particular events, the Hone and Cruikshank publications were more widely aimed at issues having to do with press freedom and Parliamentary reform. Some vestigial sense of this revolutionary tendency adheres to Kidd's Facetiae, most notably Valpurgis and The Devil's Visit.

Kidd was happy to exploit ambiguities about the authorship of some of these publications to create public interest. Monsieur Nongtongpaw was first published in 1813 by William Godwin and is often presented as a childhood production of his daughter Mary Wollstonecraft. It is, however, more probably by John Taylor, who wrote Monsieur Tonson, another of the jeux d'esprit republished at this time. One important element in the emergence of the facetiae as a literary form was the controversial publication of The Devil's Walk in 1830 which initiated an extended bout of publications that revelled in the nature of Romantic authorship and especially issues to do with collaboration, piracy and the re-writing of texts. ${ }^{5}$ First published by Marsh and Miller with Robert Cruikshank engravings as the work of "Professor Porson," a second edition edited by H.W. Montagu ascribed The Devil's Walk more accurately to Southey and Coleridge. According to the Preface to the second edition, 15,000 copies had been quickly sold. Three other jeux d'esprits that played on the themes and form of this publication followed in quick succession: The Real Devil's Walk, not by Professor Porson (Effingham Wilson 1830, illustrated by Robert Cruikshank and re-issued by Kidd in 1831); The Devil's Progress "by the Editor of the Court Journal" (Lupton Relfe 1830, with Seymour illustrations) and The Devil's Visit

${ }^{4}$ Kidd's lists advertised these publications together as "Popular Jeux D'Esprit, \& c. \& c. illustrated By Cruikshank, Seymour and Others." The assembled texts included publications built round short comic texts, polemical pamphlets and serio-comic 'trips' to leisure resorts, all issued as pamphlets using both full-page and vignette wood engravings by artists who were usually named.

${ }^{5}$ See "Other Romantic Devils" in the Introductory Materials to Reimann and The Devil's Walk (http://www.romantic-circles.org/editions/shelley/devil/Otherdev.html) for a full description of the genesis and significance of the poem. In summary, Southey's poem The Devil's Thoughts, begun for amusement while shaving, became popular through its many unauthorized reprintings under various titles over the years. Richard Porson (1759-1808), a Cambridge classical scholar who was also a radical Whig apologist, even tried to take credit for composing it. Imitated by Byron, Southey finally claimed his and Coleridge's authorship of the poem in 1827 while extending and re-writing it as The Devil's Walk, a title already used by Shelley in 1812. The poem's use of the Romantic trope of the Devil wandering through contemporary London formed the basis for attacks on a range of professions, injustices and social institutions. This trope proved still valuable for satirical purposes in 1830, as these publications suggest, bringing political dissent to the jeux d'esprits genre much in the manner of the Hone/Cruikshank pamphlets from 1819-1821. The "Devil at large" trope was deeply inscribed into the cultural imaginary in the early 1830s, and gave rise to a periodical illustrated with wood engravings by Seymour and Horngold that was issued in 1832 under the successive titles of The Devil in London, Asmodeus, or the Devil in London and Asmodeus in London. The journal was published under the volume title of The Devil's Memorandum Book (see Wiener 1970: 14). 
(William Kidd 1830, again illustrated by Robert Cruikshank). It is interesting that these various Devil texts, which brought a polemical and satirical edge to the jeux d'esprits genre, were largely not originally published by Kidd but added to his list later in the 1830s, by which time their controversial nature would have quietened down. Published in an identical format to the more diversionary facetiae, these publications maintained a tradition of Regency graphic political satire on into the 1830 s and continued to influence caricaturists like C.J. Grant. Robert Cruikshank was certainly a graphic satirist who was well aware of the tradition of wood engraved political commentary, as suggested in Cruikshank v. Agnew and Cruikshank v. the New Police in Cruikshank's Comic Album, one of several undated collections of the jeux d'esprits that Kidd published in 1832 and 1833. Although the satire in Kidd's more adventurous facetiae never recaptured the political intensity of the Hone/Cruikshank pamphlets, the critique of contemporary society in a few of his pamphlets at least acknowledged an important tradition of radical graphic commentary in the Regency period and should be offset against the accusation of triviality that might be launched at much of his list.

The texts of the less overtly satirical and diversionary facetiae needed to be long enough to justify separate publication, but not long enough to challenge the attention span of the reader. The length, the use of the comic mode and the prominence of illustration defined the facetiae as relatively undemanding leisure reading for a fairly sophisticated if not exceedingly affluent market. That they were issued in paper covers suggests both a certain ephemerality - an evening's diversionary read rather than something for the library shelf - but nevertheless the possibility that purchasers would still be affluent enough to bind up their favourites for their studies and libraries. Kidd, through the use of the republications that I list in the bibliography below, increasingly directed the facetiae, gathered into volume form, towards the library shelf. The small size of the publications and the combination of full page and vignette illustrations emphasized the newly recognised artistic potentiality of the wood engraving. The illustrations clearly aimed to build a bridge between the aesthetic ambitions of the vignette, which were being explored at exactly the same time in such diverse publications as Turner's illustrations to Rogers's Italy (1830) and the emergence of humorous wood engraving in George and Robert Cruikshank's varied contributions to comic publications. In this sense Kidd's facetiae are puzzling, at once downmarket but maybe upmarket once bound, recycling the old and yet avant-garde in their experimentational spirit.

Given their relatively insubstantial form and Kidd's reliance on the bundle or Sammelband to give weight to more elaborate re-publication, it is unsurprising that the facetiae were frequently assembled into multi-volume gatherings, which only, of course, adds to their bibliographical complexity. The most notable anthology was the two-volume 1831 Facetiae that drew together eleven reprinted works all illustrated by Robert Cruikshank. But other gatherings of assorted facetiae appeared, some perhaps the product of Kidd's non-stop entrepreneurial efforts to re-use available texts, but others the result of individual purchasers binding up chosen gatherings of their favourites. The two volume Cruikshank's Comic Album for example, gathered some of Robert Cruikshank's more polemical pamphlets together in the first volume while devoting a second volume to "humorous poetry." While the title pages to both volumes (volume 1 is dated 1832), give William Kidd as publisher, the individual elements included are still offered under the imprint of their original publishers, suggesting that Kidd had either bought up the blocks and purchased the right to reprint the texts or was indifferent to accusations of piracy. 
The illustrations in the facetiae formed something more substantial than the texts. Indeed, the combination of full-page illustrations and tiny graphic ornaments dropped into the text in the manner of late eighteenth-century volumes of poetry contributed significantly to the idea that the small-scale wood engraving might be a serious rival to metal engraving or etching as an ambitious and aesthetically sophisticated graphic medium. Robert Cruikshank, by the early 1830s a pretty well-known comic artist, was the artist of choice for most of the facetiae, but Thomas Landseer and Robert Seymour, established artists in their own right, were also called on by Kidd. As a technical matter, translating the work of these well-known artists into print required the services of expert wood engravers, and here Kidd drew from the best of a newly established but increasingly important London trade group. The publication of an edition of Northcote's Fables in 1828 had brought the skills and ambitions of the London wood engravers to public notice, and, among the engravers used by Kidd, both Matthew Sears and Samuel Slader had contributed to this volume. In addition to Sears and Slader, many of the engravers Kidd called upon - G.W. Bonner and Edward Evans, for example - went on in the later 1830s and 1840s to work for ground-breaking illustrated projects like the Penny Magazine, the Penny Cyclopaedia and the Illustrated London News. Samuel Williams worked extensively for the Olio, the most ambitious cheap illustrated fiction bearing weekly magazine. ${ }^{6}$ Williams, like Bonner, trained a subsequent generation of engravers in their workshops. Sears moved to France in the 1830s as one of a considerable number of British trained engravers whose work was much sought after in Europe. However lightweight the facetiae might appear in literary terms, their illustrators and engravers represented a moment when the wood engraving was beginning to substantiate its claims to be taken seriously as an illustrative medium. And here the borders of these emerging careers were still porous: Seymour, for example, was an expert engraver, but also made a career as an illustrator who, unlike most engravers, signed his images even if he could not always profit from each reuse.

Robert Cruikshank remained undoubtedly Kidd's star attraction and, quite aside from the jeux d'esprits, the publisher found many ways to show off his work, again using titles that both muddied the distinction between George and Robert by a generic use of the Cruikshank name and other misrepresentations that gave an overstated dignity to projects that were often little more than attractively illustrated miscellanies of previously published short comic fictional anecdoes. The four volumes that comprised a series sometimes called Cruikshank's Comic Library, but more frequently known as Cruikshank at Home, were issued successively as single volumes and then re-issued as double volumes. One important outcome of the first volume of The Comic Library, published initially as The Odd Volume, was the introduction, with a suitable rhetorical editorial flourish, of Robert Seymour to a wider audience than he had previously enjoyed as a jobbing engraver and house artist to the publishing form of Knight and Lacey. ${ }^{7}$

\footnotetext{
${ }^{6}$ See Engen 1985 for entries on individual engravers.

${ }^{7}$ The Preface to The Odd Volume declared that the publisher has "the additional pleasure of announcing the Engravings are the joint production of two clever artists - the one, Mr. Cruikshank, a long-established favourite - the other, Mr. Seymour, a gentleman of far superior talent, but hitherto not quite, perhaps, so extensively known, in consequence of his short residence in London." (n.p.) While Kidd made extensive use of Seymour in other publications, he never had "the entire management of all future volumes - so far, at least, as relates to the Illustrations" suggested by the Preface.
} 
Equally significant was the address to families suggested by the phrase "Cruikshank at Home." Until the 1830s, graphic humour had been implicitly ascribed to a male readership, and considered too coarse for women, but the print entrepreneurs operating in the early $1830 \mathrm{~s}$ had recognised that, given the advantages and popularity of the wood engraving, comic illustration was an important commodity that could be marketed to a rapidly growing readership of women. Louisa Sheridan's Comic Offering, launched in 1830 and surviving for five yearly volumes, cleverly offered women readers a comic version of the genteel annual that assured them that rules of good taste would never be transgressed. ${ }^{8}$ Once again, Kidd had picked up the opportunities offered by the changing market place and ran with them. Cruikshank at Home was a clever title it suggested an artist at home with his material as well as publications aimed to be shared at home, around the domestic fireside. At the same time that Kidd deliberately deceived the public by insinuating that Cruikshank at Home was the famous Cruikshank and not the Cruikshank he had actually hired, he was helping to create a new market for the female reader interested in graphic humour.

Kidd's persistent repackaging of Robert Cruikshank's work into new combinations suggests both how central the artist was to the publisher's commercial survival and how important the small-scale comic wood engraving had become as a print commodity. As well as Cruikshank at Home, which eventually stretched to four volumes, there was a three-volume Cruikshank's Cabinet Library and a set of Illustrations to the Unknown Tongues published separately from its accompanying text. Kidd even promised something called Kidd's, Cruikshank's and Seymour's Parlor Portfolio. A Perennial of Entertainment, a gathering of the artists' work that was announced as a Christmas album after Seymour's death in 1836. Although Kidd advertised this volume with extracts from a review in the Morning Post, I have not been able to find an extant copy. It might, of course, have actually appeared under quite another title. Nevertheless, "Kidd's, Cruikshank's and Seymour's" showcases two visual artists alongside their publisher as the marketable authors.

William Kidd's career as a publisher epitomises an important strand of print culture in the 1830s. The democratisation of readership that had begun in the cheap weekly miscellanies and "useful information" magazines of the 1820 s had been reinforced in the early 1830s by the institutionalised cultural weight of such organisations as the Society for the Diffusion of Useful Knowledge and the entrepreneurial skills of publishers like the Chambers Brothers and John Cassell. The defining texts of "the march of intellect," most notably the Penny Magazine and the Saturday Magazine, had fully incorporated the wood engraving into their cultural mission. Such magazines and related publications addressed the artisan classes by constructing a powerful model of social change driven by an informed and aspirational workforce. At the same time and by contrast, the potentialities of the mass market in print released by new technological and commercial understanding were being made available to a large swath of non-artisan middling classes as both informative and leisure reading. As his publications make clear, Kidd knew (or thought he knew) how to attract the interest of a slightly different readership than those drawn to publications aimed at fulfilling the cultural ambitions of the artisan classes. Many of his

\footnotetext{
${ }^{8}$ Sheridan became involved in a lively debate about the potential coarseness of graphic comedy with Thomas Hood, described by Katherine Harris in Forget Me Not, 154-162.
} 
publications were aimed at a newly eager readership with social aspirations but uncertain of the behaviour and code of manners appropriate to their ambitions. Others, especially the facetiae, reconfigured literary texts in ways that made them an attractive and undemanding read while retaining some sense of their status as literature. For such readers, Kidd divided down texts into easily digestible elements produced in pocket sized units, enlivened by small scale wood engraved illustrations, but still capable of being amassed into more substantial publications. These basic textual elements proved to be a resource that could be endlessly revisited, thus leading to a bewildering succession of previously published material being re-assembled and issued under new titles. However repetitive, these efforts nevertheless resonated in the creation of a mass audience.

Kidd's business sense was dependent not just on his reading of the developing marketplace for cheap print, but on cutting his costs in ways that frequently led to sharp practice. In the context of this special issue of the Victorian Popular Fictions Journal, it is worth emphasising that Kidd cut back on costs largely by eliminating the need for authors. Nearly all his publications except the jeux d'esprit were anonymous, and often compiled rather than written, presumably the work of hired hacks or even Kidd himself. In this sense, the publisher was indeed, as George Cruikshank splenetically declared, "Thief Kidd," preferring to steal texts rather than commission them. Even the texts of the jeux d'esprits were largely reprints of minor works by authors who were dead or unlikely to bother with issues to do with copyright. Images wandered among publications presumably without further payment to the artists, Kidd perhaps having secured his rights to the blocks when they were first commissioned. Kidd's advertisements were specious, boastful and deliberately misleading. As suggested above, his overstatements sometimes resulted in bitter public rows with authors and illustrators, which Kidd seems to have relished as free publicity. The continuing recycling of publications by gathering them into new combinations under variant titles frequently offered an illusory sense of freshness and variety to his list. In all these practices, Kidd was probably no worse than many under-capitalised London publishers who were just scraping by or falling into bankruptcy.

Yet however cynical Kidd's approach to the literary market may have been, his publications were materially more complex and attractive than their derivative origins might suggest. Illustration was central to Kidd's vision of popular publishing, and he gave the small-scale wood engraving, even in the form of small-scale vignettes, an emphasis and dignity that contrasts with the use of the form in publications like the Penny Magazine, where little or no acknowledgement was given to the creative energy of the illustrations. Kidd's dealings with illustrators show tensions between sharp business practices and an enlightened and forward-looking interest in using the best available resources. He brought into visibility a new generation of draughtsmen and the expert wood engravers who had emerged to work on their drawings. Kidd did much to establish both the wood engraving and the names of its leading practitioners in public consciousness by acknowledging and publicising, however spuriously sometimes, the names and work of his illustrators. His publications were densely populated by a crowd of significant named draughtsmen and engravers led by Robert Cruikshank and Robert Seymour. Seymour, previously a largely anonymous house artist for Knight and Lacey, was in particular helped towards prominence by his association with Kidd (Maidment 2021: 25-42). Kidd took up the potentiality of the small humorous wood engraving and transferred illustrations in this idiom out of periodicals like Bell's Life in London and comic 
annuals like Hood's Comic Annual into mainstream publishing. In the process, Kidd invented new print genres that both accommodated and were built round the attractions of the wood engraving and which accelerated the wider acceptance of the wood engraving as a comic medium. For all the repackaging, retitling, and recycling, some of which condescended to an emerging class of readers, Kidd's commercial enterprises integrated the humorous wood engraving into a literary market now poised to communicate to a mass audience in a dynamic new idiom.

\section{Bibliography}

\section{Primary Sources}

Many of William Kidd's publications were published anonymously. Frequently his books and pamphlets were undated, thus allowing him to republish them from available sheets in various new combinations. What follows is a list of those of Kidd's publications that I have consulted in the preparation of this article, together with those Facetiae which were often bound together with Kidd's works, and which I have drawn on in my discussion of the Facetiae genre.

The Book of Books. n.d. London: William Kidd.

This volume comprised 4 short items which were also published separately:

1. London In All Its Glory;

2. The London Ambulator;

3. London And All its Dangers;

4. London And All Its Miseries.

Brighton. n.d. London: William Kidd.

Chesterfield Modernised. n.d. London: William Kidd.

Coleridge, Samuel Taylor and Southey, Robert. 1830. The Devil's Walk. London: Marsh and Miller.

The Comic Coronal. 1832. London: William Kidd.

This volume comprised:

1. Walks About Town;

2. Monsieur Tonson;

3. The Mayor of Garrett;

4. The High Mettled Racer;

5. The Devil's Visit;

6. Margate.

Comic Magazine. 1832-34. 4 series. London: William Kidd/Gilbert/National Library.

The Condition of the West India Slave. n.d. London: William Kidd.

"Correspondence." 1832. Athenaeum. (7 July and 14 July), Nos. 245 and 246.

Cruikshank, George. 1834. My Sketch Book. London: George Cruikshank. 
Cruikshank at Home. n.d. 4 series (volumes). London: William Kidd.

The volumes comprise

1. A New Family Album of Endless Entertainment.

2. The Humourist.

3. Cruikshank's Offering of Mirth, Or, Evergreen of Fun.

4. The Odd Volume Fourth Series.

Cruikshank's Cabinet Library. n.d. London: William Kidd.

Cruikshank's Comic Album 1832. 3 volumes. London: William Kidd.

The volumes comprise:

1. First Series: Valpurgis; Cruikshank v the New Police; The Condition of the West India Slave; Walks About Town; Unknown Tongues.

2. Second Series: Monsieur Tonson; Monsieur Nongtongpaw; Monsieur Mallet; Matthews's Comic Annual; The Devil's Walk.

3. Third Series: Walks About Town; Monsieur Tonson; Valpurgis; High Mettled Racer; The Devil's Visit; Margate.

Cruikshank's Illustrations to Unknown Tongues. 1833. London: William Strange.

Cruikshank v. Agnew. 1833. London: William Kidd.

Cruikshank $v$ the New Police. n.d. London: William Kidd.

Dibdin, Thomas. 1831. High Mettled Racer. London: William Kidd.

Dibdin, Thomas. 1830. Monsieur Nong-Ton-Paw. London: J.Chappell.

Egan, Pierce. 1831. Matthews Comic Annual London: Alfred Miller.

Facetiae. 1831. 2 volumes. London: William Kidd.

The volumes comprise:

1. The High Mettled Racer; Monsieur Nongtongpaw; Monsieur Tonson; Margate; Mathew's Comic Annual; March of Intellect; Monsieur Mallet.

2. Old Booty!; The Devil's Walk; The Devil's Visit; The Real Devil's Walk; Brighton; Steamers and Stages.

Foote, Samuel. 1831. The Mayor of Garratt: a Comedy in Two Acts. London: Alfred Miller/Thomas White. Golden Records; A Miniature World of Wisdom. n.d. London: William Kidd.

Hervey, T.K. 1830. The Devil's Progress. London: Lupton Relfe.

Hood, Thomas? 1830. Steamers v. Stages. London: William Kidd.

Hood, Thomas. 1829. The Epping Hunt. London: Charles Tilt.

Illustrations to the Unknown Tongues. n.d. London: William Kidd.

Kidd's Golden Key to the Treasures of Knowledge. n.d. London: William Kidd.

Kidd's New Guide to the 'Lions' of London. 1832. London: William Kidd.

Leigh's New Picture of London; or, a View of the Political, Religious, Medical, Literary, Municipal, Commercial and Moral State of the British Metropolis. 1830. London: Samuel Leigh.

Margate - A Humorous Poem. 1831. London: William Kidd.

The Modern Brummell. n.d. London: William Kidd.

Moncrieff, W.T. 1830. Old Booty. London: William Kidd.

Moncrieff, W.T. 1830. The March of Intellect. London: William Kidd.

Montagu, H.W. 1830. Walks About Town. London: William Kidd.

Montagu, H.W. 1830. Monsieur Mallet. London: Thomas Griffiths. 
The Odd Volume, or, Book of Variety. n.d. London: William Kidd.

Oldfield, F. 1830. A Trip to Greenwich. London: J. Chappell.

Oldfield, F. 1830. A Trip to Richmond. London: J. Chappell.

Oldfield, F. 1830. The Deputy's Dinner. London: J. Chappell.

Oldfield, F. 1830. The Mill. London: J. Chappell.

Picturesque Pocket Companions. 1831-1835. London: William Kidd.

Quiz, Junior. 1837? Characteristic Sketches of Young Gentlemen. London: William Kidd.

The Real Devil's Walk. 1830. London: Effingham Wilson.

Sayings Worth Hearing. n.d. London: William Kidd.

Seymour's Comic Album. 1836. London: William Kidd.

Shelley, Mary. 1830. Monsieur Nongtongpaw. London: Alfred Miller.

Steamboat Companions. 1831-1835. London: William Kidd.

Streams of Knowledge from the Fountains of Wisdom. n.d. London: William Kidd.

Taylor, Robert. 1830. Monsieur Tonson. London: Alfred Miller.

Teasing Made Easy - showing How to Excel in that most fashionable of all Modern Accomplishments. n.d. London: William Kidd.

"A Valetudinarian." 1835. Seaside Reminiscences: A Collection of "Odd Thoughts" Picked Up at the Chief Watering Places on the Southern Coast of England. London: William Kidd.

Valpurgis; or, The Devil's Festival. 1830. London: William Kidd.

Wight, John. 1824. Mornings at Bow Street. London: James Robins.

The Yorkshire Hunt. 1830. London: March and Miller.

\section{Secondary sources}

Anderson, Christopher Gangadin. 2018. London Vagabond - The Life of Henry Mayhew. London: Chris Anderson.

Browning, Logan D. Jnr. 1991. "William Kidd." Dictionary of Literary Biography Volume One Hundred Six - British Literary Publishing Houses 1820-1880, 162-164. Detroit and London: Bruccoli Clark Layman.

Engen, Rodney K. 1985. Dictionary of Victorian Wood Engravers. Cambridge: Chadwyck-Healey.

Feely, Catherine. 2014. "What say you to free trade in Literature? The Thief and the Politics of Piracy in the 1830s." Journal of Victorian Culture, 19.4: 497-506. DOI: https://doi.org/10.1080/13555502.2014.967545

Harris, Katherine D. 2015. Forget Me Not: The Rise of the British Literary Annual, 1823-1835. Athens: Ohio University Press.

Hunt, Tamara L. 1996. "Louisa Henrietta Sheridan's 'Comic Offering' and the Critics: Gender and Humor in the Early Victorian Era." Victorian Periodicals Review, 29.2: 95-115. https://www.jstor.org/stable/20082913

Klancher, J.P. 1987. The Making of English Reading Audiences, 1790-1832. Madison: University of Wisconsin Press.

Long, William F. 2020. "The Two Versions of Sketches of Young Gentlemen," Dickens Quarterly, 37.1: 7-28. DOI: https://doi.org/10.1353/dqt.2020.0002 
Maidment, Brian. 2010. "Dinners or Desserts? - Miscellaneity, Knowledge and Illustration in Magazines of the 1820s and 1830s," Victorian Periodicals Review, 43.4: 353-87. https://muse.jhu.edu/article/409899

Maidment, Brian. 2013. Comedy, Caricature and the Social Order 1820-1850. Manchester: Manchester University Press.

Maidment, Brian. 2021. Robert Seymour and Nineteenth Century Print Culture: Sketches by Seymour and Comic Illustration. Abingdon: Routledge.

Patten, Robert. L. 1992 and 1996. George Cruikshank's Life Times and Art, 2 vols. Cambridge: Lutterworth Press.

Rickwood, Edgell. 1971. Radical Squibs and Loyal Ripostes. Bath: Adams and Dart. Fraistat, N. and Raiman, D.H., Eds. 1997. "Introduction to the hypertext edition of The Devil's Walk." Romantic Circles. www.romantic-circles.org.Accessed 18/11/2021.

Runyan, W.R. 1975. "Bob Southey's Diabolic Doggerel: Its Influence on Shelley and Byron," The Wordsworth Circle, 6.4: 249-54. DOI: https://doi.org/10.1086/TWC24039323

Schlick, Paul. Ed. 2012. Charles Dickens: Sketches of Young Gentlemen and Young Couples. Oxford: Oxford University Press.

Wiener, Joel H. 1970. A Descriptive Finding List of Unstamped British Periodicals 1830-1836. London: Bibliographical Society.

Watkins, M.G. and Mathews, H.G.C. 2004. "William Kidd," Oxford Dictionary of National Biography. http://doi.or/10.1093/ref:odnb/1557

Wood, Marcus. 1994. Radical Satire and Print Culture 1790-1822. Oxford: Clarendon Press. 